\title{
UPAYA PEMENUHAN KEBUTUHAN AIR BERSIH RUMAH TANGGA PADA DAERAH TERCEMAR PB DESA DUKUHSARI KECAMATAN JABON KABUPATEN SIDOARJO
}

\author{
Febri Meliawati, Iva Rustanti, Rachmaniyah
}

\begin{abstract}
Fulfillment of clean water should be related to consumption for human health. This research purposed to describes the fulfillment of household clean water which PB polluted area in Dukuhsari village Jabon district Sidoarjo Regency with 94 number.

The sources of clean water in all household in Dukuhsari from ground water. Which the infrastructure of supply $88,3 \%$ digging well. The drinks water sources is $79,8 \%$ tank water, with $55,3 \%$ manually transportation system. The storing facility is $58,5 \%$ permanent building with cleaning intensity once a week. All clean water supply used for shower, cloth washing, plant watering.

Conclusion of this research are no household have water safe accessibility and no protected drinking water resources.
\end{abstract}

Keywords : Fulfillment of clean water

\section{PENDAHULUAN \\ Latar Belakang}

Penyediaan air bersih untuk masyarakat mempunyai peranan yang sangat penting dalam meningkatkan kesehatan lingkungan atau masyarakat, yakni mempunyai peranan dalam menurunkan angka penderita penyakit khususnya yang berhubungan dengan air dan berperan dalam meningkatkan standar kualitas hidup masyarakat.

Kecamatan Jabon Kabupaten Sidorjo adalah daerah yang seluruh wilayahnya masih belum mendapat pelayanan PDAM (Perusahaan Daerah Air Minum). Sehingga, dapat disimpulkan bahwa 11.925 rumah tangga di Kecamatan Jabon, 5.781 jiwa, dan 1.370 rumah tangga di Desa Dukuhsari sebagian besar masih menggunakan penyediaan air bersih dengan sistem non perpipaan (sumur gali, sumur pompa) untuk penyediaan air bersihnya.

Air sumur di wilayah Kecamatan Jabon Kabupaten Sidoarjo sudah tidak layak konsumsi karena mengandung unsur timbal diatas ambang batas. Sehingga air tanah di wilayah Kecamatan Jabon sudah tidak layak untuk konsumsi.

Logam timbal $(\mathrm{Pb})$ dapat masuk dalam tubuh manusia, dikarenakan manusia mengkonsumsi air minum yang tercemar logam $\mathrm{Pb}$. Timbal dapat mengakibatkan pengaruh buruk terhadap sistem saraf, fungsi ginjal, sistem kekebalan, organ seks, sistem pertumbuhan, dan sistem peredaran darah ke jantung. Pengaruh timbal juga dapat menimbulkan gangguan saraf pada anakanak, tekanan darah tinggi pada orang dewasa. Bayi dan anak-anak kecil sangat rentan terhadap timbal, sekalipun kadarnya rendah. Kadar timbal yang rendah itu dapat memengaruhi tingkah laku mereka, seperti sulit belajar dan IQ yang rendah (team sos, 2011).

\section{Tujuan}

Untuk menggambarkan upaya pemenuhan kebutuhan air bersih skala rumah tangga pada daerah yang tercemar $\mathrm{Pb}$ di Desa Dukuhsari Kecamatan Jabon Kabupaten Sidoarjo pada tahun 2013.

\section{HASIL PENELITIAN DAN PEMBAHASAN Pengadaan Air bersih \\ Sumber utama air bersih yang} digunakan seluruh rumah tangga adalah air tanah. Sumur gali adalah sumber air bersih yang digunakan oleh $83 \%$ rumah tangga. Sebagian besar sumur gali yang telah diberi tembok rapat air 3 meter dari muka tanah, sekeliling sumur diberi lantai rapat air selebar $1-1,5$ meter, memiliki saluran pembuangan pada sekeliling lantai, jarak sebagian sumur dari sumber 
pencemar lebih dari 10 meter, akan tetapi seluruh sumur yang ada tidak dilengkapi dengan tutup.

Untuk kebutuhan minum $78,7 \%$ rumah tangga membeli air tangki yang diperoleh dari mata air (Prigen). Menurut Laporan Millenium Development Goals hal ini membuktikan bahwa rumah tangga masih belum memiliki akses terhadap air minum terlindung. Karena air minum terlindung diperoleh diantaranya dari air leding (PDAM), keran umum, air hujan atau mata air dan sumur tertutup yang jaraknya lebih dari 10 meter dari pembuangan kotoran. Sumber air minum terlindung tersebut tidak termasuk jika air diperoleh dari penjual keliling, air melalui tanki, air kemasan (bottled water), sumur dan mata air tidak terlindung. $\quad 62,8 \%$ rumah tangga pada umumnya memiliki sumber air bersih yang letaknya di dalam rumah. Dengan letak sumber air di dalam rumah, maka tidak lagi diperlukan adanya perhitungan waktu tempuh untuk memperoleh air bersih.

Jarak memperoleh air untuk kebutuhan minum mayoritas rumah tangga yaitu pada jarak < 10 meter dengan persentase $82 \%$. Hal ini disebabkan banyak rumah tangga yang membeli air untuk kebutuhan minumnya di penjual keliling air tanki dari mata air prigen. Dan dengan jarak tempuh memperoleh air < 10 meter sebagian besar rumah tangga menempuh waktu $<5$ menit untuk memperoleh air minum.

Berdasarkan hasil wawancara dan observasi tentang kualitas fisik air sumur yang digunakan mayoritas rumah tangga untuk air bersih pada Tabel IV.10 disebutkan bahwa 90,4\% rumah tangga kualitas fisik air bersih yang digunakan adalah cukup. Kualitas fisik air bersih dikatakan cukup apabila terdapat antara $56 \%-75 \%$ indikator dari 6 indikator yang ada pada penilaian kualitas fisik air. Beberapa indikator tersebut terdiri dari : Air tidak berbau chlor, Air tidak berbau anyir, Air tidak keruh, Air tidak bewarna kuning, Air tidak berasa asin, Air tidak menimbulkan warna kuning pada pakaian putih.

Berdasarkan kriteria kepemilikan akses terhadap air bersih yang ditinjau dari kualitas fisik yang ditentukan dalam laporan Millenium Development Goals 2010 dan Joint Monitoring Program (JMP) WHO UNICEF 2004 bahwa kualitas fisik tersebut dilihat dari segi tidak keruh, tidak berwarna, tidak berasa, tidak berbusa, dan tidak berbau. Tetapi, pada kenyataan dilapangan air bersih pada sumur gali sebagian rumah tangga berwarna kuning jika didiamkan berhari-hari dibak dan dimasak, sedikit berasa asin, dan sebagian lainnya sedikit berbau banger.

Sehingga air bersih yang digunakan oleh rumah tangga tersebut sebagian besar hanya digunakan untuk mencuci pakaian, mencuci peralatan makan, mencuci sayuran, mandi, menyiram tanaman. Sebagian rumah tangga yang memakai air pada sumur gali untuk dikonsumsi yaitu untuk kebutuhan minum dan memasak adalah rumah tangga yang tidak mengeluhkan adanya masalah kualitas fisik air sumur yang buruk. Karena, air sumur pada $12,8 \%$ rumah tangga tersebut memiliki kualitas yang dilihat secara fisik baik atau layak karena air pada sumur gali rumah tangga tersebut memenuhi $>75 \%$ indikator kualitas fisik air.

\section{Sistem Pengangkutan Air Bersih}

$52 \%$ rumah tangga menggunakan sistem pengangkutan air bersih dengan cara manual (tidak menggunakan alat untuk sistem pengangkutannya) melainkan dengan cara disunggi atau dijinjing. Tetapi tidak sedikit masyarakat yang sistem pengangkutan air bersihnya menggunakan perpipaan dimana air yang berasal dari sumur gali dialirkan lewat perpipaan dengan menggunakan pompa listrik dengan persentase $44,7 \%$. Dengan kondisi fisik sarana pengangkutan adalah dalam kondisi baik dengan persentase $68,1 \%$. Kondisi baik tersebut yaitu tidak ada kerusakan, tertutup dan bersih.

Sebanyak $73,4 \%$ rumah tangga juga melakukan sistem pengangkutan dengan cara manual (tidak menggunakan alat untuk sistem pengangkutannya) melainkan dengan cara disunggi atau dijinjing untuk sistem pengangkutan air minumnya. Dengan kondisi fisik sarana pengangkutan adalah dalam keadaan baik dengan persentase $94,7 \%$.

\section{Pemanfaatan Air Bersih}

Disebutkan bahwa $51,1 \%$ rumah tangga memiliki tingkat pemakaian air bersih antara $50-99,9$ liter per orang per hari. Pemakaian air bersih tersebut dipengaruhi oleh tingkat aktivitas, pola hidup dan kondisi sosial ekonomi. Sebagian besar rumah tangga 
memanfaatkan air bersih untuk keperluan sehari-hari yang meliputi minum, masak, mandi, mencuci pakaian, membersihkan rumah, menyirami tanaman.

Masih terdapat rumah tangga yang menggunakan air sumur untuk konsumsi yaitu untuk kebutuhan minum dan masak. Karena $12,8 \%$ rumah tangga tersebut tidak mengeluhkan kualitas air sumur secara fisik yaitu air sumur tidak keruh, tidak berwarna, tidak berbau. Akan tetapi pada kenyataannya air dapat digunakan untuk kebutuhan minum dan memasak tidak hanya baik pada segi kualitas fisik saja, tetapi harus baik dan layak dari segi kualitas kimia, dan mikrobiologi. Dan kenyataan dilapangan terdapat kandungan $\mathrm{Pb}$ (Timbal) pada air sumur tersebut.

Logam timbal $(\mathrm{Pb})$ dapat masuk dalam tubuh manusia, dikarenakan manusia mengkonsumsi air minum yang tercemar logam $\mathrm{Pb}$. Begitu masuk kedalam tubuh, timbal akan tersebar ke seluruh tubuh melalui darah terakumulasi di dalam tulang. Tergantung pada kadar dan lamanya, timbal dapat mengakibatkan pengaruh buruk terhadap sistem saraf, fungsi ginjal, sistem kekebalan, organ seks, sistem pertumbuhan, dan sistem peredaran darah ke jantung. Pengaruh timbal juga dapat menimbulkan gangguan saraf pada anak-anak, tekanan darah tinggi pada orang dewasa. Bayi dan anakanak kecil sangat rentan terhadap timbal, sekalipun kadarnya rendah. Kadar timbal yang rendah itu dapat memengaruhi tingkah laku mereka, seperti sulit belajar dan IQ yang rendah.

Disebutkan bahwa 92,5\% rumah tangga melakukan pengelolaan air bersih untuk kebutuhan minum dengan cara di masak. Dan sebagian kecil rumah tangga yang lain tidak melakukan pengelolaan air untuk kebutuhan minum rumah tangga dengan persentase $7,4 \%$. Hal ini dikarenakan $7,4 \%$ rumah tangga yang tidak melakukan pengelolaan air untuk kebutuhan minum adalah membeli air kemasan yang bisa langsung minum.

Dalam laporan Millenium Development Goals 2010 menganjurkan untuk seluruh rumah tangga dapat mengelola air bersih untuk kebutuhan minum mereka meskipun itu dengan cara yang sangat sederhana yaitu dengan cara dimasak/direbus hal ini diharapkan untuk memutuskan mata rantai penyakit yang ditimbulkan dari kondisi hidup yang tidak sehat dan berisiko penyakit. Sehingga, seluruh masyarakat terhindar dari resiko terkena penyakit, dan masyarakat dapat belajar, bekerja dan hidup sehat sehingga kesejahteraan ekonomi masyarakat yang lebih baik dapat tercapai.

\section{Penyimpanan Air Bersih}

Disebutkan bahwa 58,5\% sarana penyimpanan air bersih yang di gunakan rumah tangga adalah berupa bangunan permanen yang digunakan sebagai penampungan untuk mandi. Sedangkan tidak sedikit rumah tangga yaitu $37,2 \%$ rumah tangga menggunakan timba sebagai sarana penyimpanan air terkait dengan posisi yang dapat dipindah-pindah ke tempat lain dengan mudah. Selain itu, timba juga digunakan rumah tangga untuk menampung air sebelum dimasak dengan tujuan kotoran yang ikut terbawa air dapat mengendap.

Untuk kondisi sarana penyimpanan air $68,1 \%$ rumah tangga kondisinya baik. Kondisi baik tersebut yaitu sarana penyimpanan air bersihnya tidak licin, bersih dan terlihat terawat, tidak terdapat kerusakan, terdapat tutup apabila sarana penyimpanan tersebut berupa timba.

Disebutkan bahwa $61,7 \%$ usaha rumah tangga untuk menjaga kebersihan sarana penyimpanan air bersih tersebut adalah seminggu sekali. Dimana rumah tangga tersebut melakukan pembersihan pada sarana penyimpanan apabila sudah kelihatan kotor dan licin. Akan tetapi, ada sebagian rumah tangga yang tidak pernah sama sekali membersihkan sarana penyimpanan air bersih dengan persentase $8,5 \%$ dengan kondisi sarana penyimpanan yang kotor, dan licin.

\section{KESIMPULAN}

1. Pengadaan Air Bersih

Sumber air bersih $88,3 \%$ rumah tangga diperoleh dari sumur gali, dilihat dari jarak memperoleh air bersih $62,8 \%$ rumah tangga adalah dalam rumah, dengan letak sumber air bersih di dalam rumah, maka tidak lagi diperlukan adanya perhitungan waktu tempuh untuk memperoleh air bersih, dan kualitas fisik air bersih 90,4\% rumah tangga adalah cukup, dilihat dari sumber air untuk minum $78,7 \%$ rumah tangga adalah membeli air di penjual air tangki mata air prigen, dengan jarak memperoleh air untuk kebutuhan minum adalah < 10 meter dengan persentase $82 \%$ dan waktu yang dibutuhkan rumah tangga untuk memperolehnya adalah $<5$ 
menit dengan kualitas fisik air yang baik dengan persentase $96 \%$. Sehingga, dilihat dari jarak dan waktu memperoleh air bersih dan air minum rumah tangga telah memenuhi syarat. Akan tetapi, rumah tangga belum memiliki akses terhadap sumber air minum terlindung.

2. Sistem pengangkutan air bersih Untuk sistem pengangkutan yang digunakan $55,3 \%$ rumah tangga adalah masih dengan sistem manual (tanpa menggunakan alat ) yaitu dijinjing atau disunggi. dengan persentase $58,5 \%$ dengan kondisi sarana pengangkutan yang baik dengan persentase $68,1 \%$. Sehingga, dilihat dari kondisi sarana pengangkutan air bersih telah memenuhi syarat.

\section{Pemanfaatan Air Bersih}

Untuk jumlah pemakaian air bersih $51,1 \%$, rumah tangga adalah $50-99,9$ liter/orang/hari. Sehingga rumah tangga berada pada akses air bersih menengah. Sedangkan untuk pengelolaan air bersih untuk kebutuhan minum adalah dimasak dengan persentase sebesar $94,7 \%$ sehingga untuk pengelolaan air bersih untuk kebutuhan minum rumah tangga telah memenuhi syarat. Karena, mayoritas rumah tangga telah melakukan pengelolaan air untuk kebutuhan minumnya.. Dan hanya $7,5 \%$ rumah tangga yang tidak melakukan pengelolaan air untuk minum karena seluruh rumah tangga tersebut menggunakan air kemasan untuk kebutuhan minumnya.

\section{Penyimpanan Air Bersih}

Untuk jenis sarana yang dipilih 58,5\% rumah tangga untuk menyimpan air bersih adalah bangunan permanen berupa bak mandi, dan usaha $61,7 \%$ rumah tangga untuk menjaga kebersihan dari sarana penyimpanan air bersih adalah seminggu sekali, yang kondisi sarana penyimpanan air bersihnya adalah cukup dengan persentase sebesar $50 \%$, Sehingga dilihat dari kondisi penyimpanan air bersih rumah tangga belum memenuhi syarat

\section{SARAN}

1. Bagi Lembaga Kesehatan Setempat Hendaknya melakukan sosialisasi tentang pentingnya menggunakan air yang kualitas airnya baik dan memenhi syarat (fisik, kimia, mikrobiologi). Sehingga masyarakat lebih tahu dampak bagi kesehatan jika mengkonsumsi air yang tidak memenuhi standart kualitas.

2. Bagi Peneliti lain

a. Agar melakukan penelitian tentang dampak kesehatan yang dirasakan masyarakat daerah tersebut karena tercemarnya air sumur oleh $\mathrm{Pb}$.

b. Agar melakukan penelitian pemeriksaan kandungan logam berat lainnya selain $\mathrm{Pb}$ yang mungkin terkandung dalam air sumur.

\section{DAFTAR PUSTAKA}

Airlanggiwati,dkk, 2011. Investigasi Beberapa Indikator Tujuan Pembangunan Milenium (MDGs) di Jawa Timur. UPN press, Surabaya.

Aula, Khanifatul. 2012. Investigasi Indikator Pencapaian Target Tujuan Pembangunan Nasional (MDG's) Tentang Kepemilikan Akses Air Bersih dan Jamban Di Daerah Pedesaan Dan Perkotaan Kecamatan Porong Kabupaten Sidoarjo Tahun 2012. Surabaya : Politeknik Kesehatan Kementerian Kesehatan Surabaya.

Departemen Kesehatan. PERMENKES No. 416/ MENKES/Per/IX/1990 tentang syarat - syarat dan pengawasan kualitas air.

Departemen PU Cipta Karya, 2005. Petunjuk Teknis Sektor Air Bersih.

Margono, 2010. Penyediaan Air Bersih. Surabaya.

Palar, Heryando, 2004. Pencemaran dan Toksikologi logam Berat. Jakarta, Rineka Cipta.

Sanropie, Djasio, 1984. Pedoman Bidang Studi Penyediaan Air Bersih (PAB). Surabaya.

Setiawan, Darma. 2006. Kebutuhan Air Bersih Tingkat Konsumsi Pada Hunian Kumuh (Studi Kasus di RW IV Kelurahan Jagir, Kecamatan Wonokromo Surabaya). Surabaya : Politeknik Kesehatan Kementerian Kesehatan Surabaya.

Sutrisno, totok, 2004. Teknologi Penyediaan Air Bersih. Jakarta, Rineka Cipta.

Team SOS, 2011. Pemanasan Global Solusi dan Peluang Bisnis. Jakarta, Gramedia Pustaka Utama. 